\title{
What Makes Some Mitigation Measures and Programs "Creative"? (And Where Does That Leave the Rest of Them?)
}

\author{
Lynne Sebastian (1)
}

\section{ABSTRACT}

A quick search on antonyms for "creative" yields obvious results such as "uncreative," "unimaginative," and "uninspired," but also terms such as "dull," "derivative," and "stodgy." In the world of cultural resources and mitigation of adverse effects, "creative" is most often opposed to "standard." That sounds like a good thing, right? Good old, reliable, dependable, predictable standard mitigation. But as we will see from the articles in this special issue, remarkable things can happen when those designing mitigation programs replace or augment "standard" approaches. What is it about a mitigation measure or program that leads us to term it "creative"? How can we expand those defining qualities of creative mitigation measures and programs to enhance the quality of standard mitigation approaches? How can we make the standard approaches, if not creative, at least not stodgy?

\begin{abstract}
Keywords: cultural resource management, creative mitigation, Section 106, National Historic Preservation Act, historic preservation, public archaeology

Una búsqueda rápida para antónimos para la palabra "creativo" produce resultados obvios tal como poco creativo, no imaginativo, no inspirado y también resultados tal como aburrido, no original y pesado. En el manejo de recursos culturales y la mitigación de efectos adversos, la palabra "creativo" se opone más a "acostumbrado." ¿Y porque no usar lo acostumbrado? La mitigación acostumbrada es segura, confiable y prevesible. No obstante, las ponencias en este número especial duemuestran que cuando las medidas o programas de mitigación incluyen métodos aumentados o alternativos, los resultados pueden ser impresionantes. Que son las calidades de medidas o programas de mitigación que nos permite llamarlos creativas? ¿Como podemos extender dichos calidades de medidas o programas para aumentar la calidad de los métodos acostumbrados de mitigación? Si no podemos convertir los métodos acostumbrados a métodos creativos, ¿Por lo menos podemos harcerlos menos pesados?
\end{abstract}

Palabras clave: el manejo de recursos culturales, mitigación de efectos adversos, la preservación histórica

This special issue of Advances in Archaeological Practice is defined by two concepts: "creative" and "mitigation." The article by Douglass and Manney addresses mitigation. As they note, under Section 106 of the National Historic Preservation Act (NHPA; https://www.nps.gov/history/local-law/nhpa1966.htm), if a federally funded or approved project will have an adverse effect on a historic property, the federal agency with jurisdiction over the project consults with a variety of stakeholders to identify measures to avoid, minimize, or mitigate the adverse effects. Although avoidance and minimization are the preferred outcomes of these consultations, very often there is no alternative that will avoid serious alteration or destruction of the historic property. In those cases, a program of mitigation measures will be designed to "resolve" the adverse effects.

Over several decades after the passage of the NHPA in 1966, agencies and cultural resource professionals came to rely on certain standard approaches to mitigation of adverse effects. For archaeological sites, excavation, recordation, and curation of artifacts and other materials (what we might call "The 3 Ds" - dig, document, and destroy) was the standard; for built-environment historic properties, recordation to the exacting standards of the National Park Service's Historic American Buildings Survey/ Historic American Engineering Record (HABS/HAER; https://www. nps.gov/hdp/habs/index.htm) program ("The 2 Ds"—document and destroy) became the standard. In effect, "standard" is just a way of saying, "This is what we always do." Is the affected property archaeological? Dig, document, and destroy. Is it a historic structure? Document and destroy. Every day, these same mitigation "decisions" are made over and over. Too often, though, they aren't decisions at all-just rote, unexamined responses.

Generally speaking, for archaeological sites "dig, document, and destroy" is the appropriate treatment, but is it always? And more

Advances in Archaeological Practice 8(3), 2020, pp. 220-224

(c) The Author(s), 2020. Published by Cambridge University Press on behalf of Society for American Archaeology. This is an Open Access article, distributed under the terms of the Creative Commons Attribution licence (http://creativecommons.org/licenses/by/4.0/), which permits unrestricted re-use, distribution, and reproduction in any medium, provided the original work is properly cited.

DOI:10.1017/aap.2020.5 
to the point, is it sufficient? There were good reasons why these "standard" mitigation approaches became the standards in the first place. They are informed by the characteristics and qualities that make historic buildings and archaeological sites eligible for listing in the National Register of Historic Places (NRHP). By the 1990s, however, both stakeholders and historic preservation practitioners began to question the adequacy and the inviolability of these standard mitigations. The result has been a growing interest in creative mitigation.

\section{WHAT IS CREATIVE MITIGATION?}

If standard mitigation is another way of saying, "This is what we always do," what is creative mitigation? Many people think of creative mitigation as something that we do in addition to or instead of standard mitigation. In the latter case, this is often referred to as "alternative mitigation," although the terms "alternative" and "creative" are often used interchangeably. Guidance from the Advisory Council on Historic Preservation (2009) provides a more nuanced view of the creative mitigation concept. In my experience, the notion that creative mitigation is something we do in addition to or instead of standard mitigation most often leads to pushback rather than to better mitigation programs. Creative mitigation viewed as an add-on will create pushback from federal agencies and applicants for federal approvals-and well it should. If they have already committed to doing "what's required" — that is, standard mitigation-why should they be expected to spend more money and time doing something that isn't required? Creative mitigation, when proposed as a substitute for standard mitigation (data recovery), generally doesn't address the reason why most archaeological sites are found significant in the first place: their data potential. This view of creative mitigation will cause pushback from colleagues-and well it should. No matter how positive the proposed alternative measures are, unless we can explain how what we are proposing will mitigate the loss of data, how are we mitigating the adverse effects at all?

I would suggest that we think of "creative" mitigation as mitigation designed specifically to fulfill the purpose of the NHPA and the Section 106 process. Remember that Section 2 of the NHPA (as originally written) states:

It shall be the policy of the Federal Government ... to foster conditions under which our modern society and our prehistoric and historic resources can exist in productive harmony and fulfill the social, economic, and other requirements of present and future generations [NHPA, Section 2].

The Section 106 regulation at 36CFR800.1(a) states, "The Section 106 process seeks to accommodate historic preservation concerns with the needs of Federal undertakings through consultation." These two important statements, taken together, tell us that a truly creative mitigation program is one that balances the needs of the project (the undertaking), the needs of the prehistoric and historic resources, and the benefits to the public. It is the balance among these three things that creates the "productive harmony" envisioned in the law, and it is this balance that constitutes truly "creative" mitigation.

\section{PUBLIC BENEFIT}

Some of the questions that were raised about the adequacy of standard mitigation in the late 1980s and 1990s arose because of a broadening in the range of historic places that were defined as being worthy of preservation, or at least of consideration, under law. As preservationists, descendant communities, and others argued for the historic importance of places of traditional cultural significance, cultural landscapes, and other types of properties that had not been included in historic preservation efforts previously, it affected our views of the concept of mitigation. The significance of many of these properties cannot be captured and preserved through recordation, or by placing objects and documents in museums and archives, or by writing a scientific treatise. The strongly consultative nature of decisions about resolving adverse effects on these types of properties led some practitioners to question the rote application of "standard" mitigation measures as they applied to archaeological sites.

Other questions about standard mitigation have come from the growing field of "community archaeology" (see Jameson and Musteaţă [2019] for worldwide examples of the community archaeology approach). Community archaeology practitioners have demonstrated the value of true collaboration between professional archaeologists and descendant and other interested communities. Collaborative approaches serve not only to strengthen public support for and appreciation of archaeology and the archaeological record but to enrich our understanding of the role that cultural heritage plays_and has played-in human history. In addition, as Dongoske points out in his article in this issue, preserving traditional associations with the material remnants of a community's past is an essential part of respecting and maintaining traditional lifeways. Traditional knowledge and studies of community values cannot substitute for scientific excavation and analysis when it comes to managing our prehistoric and historic heritage, but archaeologists have come to recognize that we can-and should-achieve a richer understanding of the past by factoring humanistic elements into our work.

The rapid growth and expansion of the field of "public archaeology" in the 1980s and 1990s (see Ellick [2016] for an excellent summary) was a recognition of the importance of including benefits for the public into the practice of archaeology. Public archaeology-then and now-focuses on creating engaging information about the archaeological record and the archaeological past and making this information available to various public audiences. These outreach efforts are seen as a way to build public support for archaeological research and for the preservation of the archaeological record from both looting and unregulated development. They are also seen as a mechanism for giving back to the American people who, in one way or another, pay for nearly all of the archaeology that is done in this country, especially that carried out in compliance with Section 106 of the NHPA.

The public education field grew through conferences and workshops, publications, federal agency programs, and major efforts organized by public education task forces and committees within the Society for American Archaeology, the Society for Historical Archaeology, and many local and regional archaeological organizations. These efforts yielded an extraordinary amount of 
informational materials and programs for educators, children, communities, the traveling public, and general audiences.

The underlying principle of all this work, as applied to mitigation of adverse effects on archaeological sites, has been that the 3 Ds (Dig, Document, and Destroy) isn't enough. We need a fourth D: Disseminate. Some of the earliest "creative mitigation" for projects in archaeology involved incorporating public outreach components into standard mitigation. Public tour days, preparation of museum exhibits, development of teaching materials aligned with state curriculum standards, public lectures, websites, videos, incorporation of Native American perspectives into excavation and analysis reports-the range, quality, and variety of public products and events that have been created as part of mitigation programs have been remarkable (for an example, see article by Tull in this issue). Unfortunately, substantial efforts to provide public benefits and balance those with the needs of both the undertaking and the resources are still the exception rather than the rule in Section 106 mitigation programs.

We produce enormous amounts of archaeological data every year. Where we fall short is in synthesizing those data into knowledge about the past and then sharing that knowledge with the public. Such knowledge production requires several things, but we especially need to improve the accessibility of this mass of data that we have been collecting (e.g., McManamon et al. 2017), and we need funding sources to support synthesis efforts (e.g., Coalition for Archaeological Synthesis 2018).

A third type of public benefit is one that we rarely talk about, even though it is specifically called out in the law: "to fulfill the social, economic, and other requirements of present and future generations." We all need good roads and adequate water supplies. We want the lights to come on when we press the switch and the heat to come on when we raise the thermostat. We want the minerals that power our cell phone batteries and build our wind turbines and ensure that our smoke detectors keep our families safe. When we design a compliance process that balances the needs of the resources and the needs of the undertaking with consideration of this and the other types of public benefit, we are, by definition, creating a public good.

\section{THE NEEDS OF THE UNDERTAKING}

Most of the early proposals for archaeological mitigation measures other than the standard 3 Ds were referred to as "alternative" mitigation (e.g., Klein 1994). In many instances, these proposals were a result of a compliance process that failed to take into account the needs of federal undertakings and those who proposed to carry them out. Generally, these alternatives were offered by industry or developers who hoped to save time and money on the compliance process. Many were modeled on approaches used in compliance with the Clean Water Act, especially "mitigation banking" and "off-site" mitigation.

\footnotetext{
"Mitigation banking" refers to restoration, enhancement, or creation of wetlands or habitat. These efforts are carried out to offset the destruction of wetlands or habitat that results from project development. Creation of new archaeological sites was clearly out of the question, but proposals were made to substitute acquisition
}

and protection of an important, privately owned archaeological site threatened by such events as looting, erosion, and urban sprawl for excavation of the actual archaeological sites located within the project area. This was sometimes a tempting offerthere are always important sites under threat that we would dearly love to find a way to save. It may be that the original and the constructed wetlands are fungible. I wouldn't want to speak for our botanist colleagues on the subject. Archaeological sites, however, definitely are not.

Off-site mitigation proposals, on the other hand, involved the project proponent offering to pay for excavation and analysis of one or more "really nice sites" outside the footprint of the project area in order to avoid having to wait for excavation to be completed on the "mundane sites" within the right-of-way. This approach had the same problem as mitigation banking: the information in these various sites is not interchangeable. One of the best things about NHPA-driven archaeology was that it forced us to examine the entire archaeological record and not just the "good" sites. The off-site mitigation approach would have been moving us back toward the pre-NHPA days. In addition, off-site mitigation would have meant that even more archaeological sites would be destroyed, some by bulldozer in the project area and some by archaeologists outside of it.

Although many of the alternative mitigation proposals were nonstarters for the reasons outlined above, they led some historic preservation practitioners to think more carefully about incorporating the needs of undertakings and project proponents into planning for Section 106 compliance, in general, and mitigation programs, in particular. I have spent much of my career working with mining companies, pipeline companies, and energy development companies. In my experience, the great majority of them want to do the right thing. The Leaders in Energy and Preservation cooperative program (LEAP 2019) is an excellent example of the promise of a cooperative relationship between preservationists and industry. Project proponents know more about the details of the undertaking than anyone. They can tell you what will and won't work for the project, and they can often come up with excellent ideas for avoiding, minimizing, and mitigating the effects on historic properties.

Treating project proponents like an enemy of preservation never pays off, and it often leads to missed opportunities. The proponents and their employees are members of the public, and they can be a great source of ideas about mitigation measures that will provide public benefits. Project proponents can become truly interested in the archaeology that they are being asked to preserve, whether physically or through data recovery, if we take the time to explain the significance of the work in laymen's terms. I view every undertaking as an opportunity to create an advocate for archaeology, and frankly, if we can't even make this interesting to the person who is paying for the work, what are the chances that we are going to be able to engage the public?

The approach discussed by Larralde and colleagues in this issue (see also Larralde et al. 2016) is a good example of a mitigation program that takes into account the needs of the undertakings and balances those with the needs of the resources and the benefit to the public. Energy development in the portion of the Permian Basin that lies within southeastern New Mexico has gone 
on for many decades-so long, in fact, that the first gas well ever drilled in that region has been deemed a historic property and is listed on the New Mexico State Register of Cultural Properties! Over time, large areas of the landscape have been entirely transformed with well pads, roads, pipelines, tanks, injection wells, mud pits, and all of the endless variety of ground-disturbing activities associated with oil and gas development.

After the protections of Section 106 of the NHPA were extended to cover "eligible" historic properties as well as NRHP-listed properties in 1972, archaeological resource management in the oil and gas fields of southeast New Mexico came to mean "survey the footprint of every development and avoid disturbing the eligible sites." Over time, several problems with this approach became clear. First, we ended up avoiding pretty much all the sites. Because we almost never dug or even tested many sites, we had no way of making really informed eligibility decisions. Second, development became so dense in many of these fields that proponents had to turn their projects into pretzel shapes trying to shoehorn another flowline or storage tank into a landscape full of "avoid at all costs" sites. Third, this kind of density of development inevitably led to inadvertent damage and degradation for the archaeological sites. The oil and gas industry began to ask whether there was another way to go: Do we really need to avoid all these sites? Do we have to keep doing archaeological surveys of every project in areas that have already been surveyed so thoroughly? (See Heilen's article in this issue for approaches to answering this question.) What is the point of preserving all this archaeology as far as the public is concerned?

As Larralde and her colleagues describe in this issue, through consultation among industry, the Bureau of Land Management (BLM), the State Historic Preservation Office (SHPO), tribes, and the archaeological community, a new, unique programmatic approach to archaeological resource management was adopted. This approach does an excellent job of balancing the needs of the undertakings (industry has more flexibility in siting development and saves time on projects that don't require surveys), the needs of the resources (industry-funded research is finally allowing agency archaeologists to make better decisions about site significance and management and to target sites for excavation where inadvertent damage is most likely), and the public benefit (requirements to share results of industry-funded research with the public are written into the programmatic agreement document).

\section{THE NEEDS OF THE RESOURCES}

The standard dig, document, and destroy approach to mitigation for archaeological sites is entirely focused on the needs of the resources, and this would seem to be a good thing. But when we view the 3 Ds as the be all and end all of mitigation, we are acting as if the purpose of Section 106 is for archaeologists to acquire a lot of cool data about the archaeological record. It is not. Not only does the lack of attention to the needs of the undertaking and the public benefit leave the mitigation program lacking the balance intended by the law and the regulation, but it can engender both resentment of the process among those trying to carry out development projects and apathy among the public. It can also lead to a myopic view of how best to advance our understanding of life in the past.
I would like to offer a couple of case examples in which I was involved earlier in my career. In these cases, close attention to balancing the needs of the resources with the needs of the undertaking, combined with an awareness of the importance of public benefits, produced a better result for archaeology, preservation, and our understanding of the past than straightforward "dig, document, and destroy" would have done.

The first project, the Fruitland Coal Gas program in northwestern New Mexico (Brown et al. 2014; Chandler 2009:127-129; McManamon et al. 2016), was a massive energy development in the late 1980s and 1990s that resulted in drilling of more than 3,000 gas wells and construction of more than 600 miles of pipeline within an area of some 1,350 square miles. Section $106 \mathrm{com}$ pliance for all of this development was complicated by a very high site density (up to 75 sites per square mile), the involvement of multiple independent energy companies employing multiple independent cultural resource management firms, and a soon-to-expire tax credit for development of "nontraditional energy sources" that made everything time critical. One of the public benefits in this case was greater energy independence for a country that had been rocked in the previous decade by two energy embargos that created worldwide shortages. Another benefit was the opportunity for us to interpret for the public two archaeological cultures - the Pueblo I period and the early Navajo period-that were not well known in the region.

The BLM and SHPO responded to the needs of the undertaking and the needs of the resources by negotiating a memorandum of agreement that treated all coal-gas-related activity as if it were part of a single undertaking. This allowed us to respond systematically and creatively to the industry's need to carry out the development very quickly. It also enabled us to consolidate what could have been a chaotic, incompatible mass of archaeological data into a unified archaeological program, in which all surveys, excavations, and analyses were carried out under a single research design and a program-wide set of data-comparability guidelines. The Fruitland project also included a major ethnographic study to provide context for the large number of early Navajo sites at a time before such efforts were common. Although there were grumblings and some misgivings at first, industry, the agencies, and the members of the archaeological profession came to recognize that the Fruitland approach to creative mitigation was a Good Thing. When industry representatives began asking whether there was any way to bring conventional gas developments under the Fruitland coal-gas umbrella, we knew that we were onto something.

The second project that I would like to highlight was called Border Star 85. This 1985 U.S. Army, Air Force, and Marine Corps joint readiness exercise on White Sands Missile Range and Fort Bliss lands in southern New Mexico involved some 30,000 personnel, 2,500 wheeled vehicles, and 500 tracked vehicles. The needs of the undertaking were for large-scale, realistic, unconstrained training areas in a desert environment. At this time, only five years before the outbreak of the Gulf War, the military knew where future engagements were likely to be fought. The public benefit in this case was that a well-trained military is important for our national defense, and training as a life-saving measure for American soldiers, marines, and airmen is certainly a public good as well. 
The problem was how to take into account the effects of such a massive operation, especially the training that involved tracked vehicles, on a very large number of archaeological sites. There was no time or funding for an enormous excavation program, and not all of the identified sites (Seaman et al. 1988) could be avoided, as this would be incompatible with the training needs. The creative mitigation solution was (1) to carry out a landscape-scale study of the archaeology in the training areas with in-field analyses of the sites and artifacts and (2) to set aside a limited number of "reserves" clusters of significant sites that would be off-limits for training.

One of the vexing issues of this approach was how to effectively protect the reserves from training impacts, especially by the tracked vehicles. The solution? These were war games; the military units were guided during maneuvers by detailed maps showing targets and hazards. At our request, all of the reserves were shown on the maps as mine fields. At the suggestion of one of the military planners, the GPS coordinates of these "mine fields" were also encoded into the on-board computers of the tracked vehicles. If any vehicle strayed into a mine field, it would "blow up" that is, the engine would stop running, eliminating the vehicle and its crew from further participation.

As a result of this approach, the military personnel had the realistic training that they needed, and the archaeological reserves were not only protected but actually contributed to the verisimilitude of the training. This synergistic relationship, resulting from thoughtful balancing of the needs of the resources and the needs of undertaking, yielded creative mitigation at its best.

\section{HOW DO WE KEEP MITIGATION FROM BEING "STODGY"?}

The "standard" 2 D and 3 D mitigations will always be an important part of resolving adverse effects on historic structures and archaeological sites because these approaches are based on the qualities and character-defining features that make these properties eligible for listing in the NRHP. These standard approaches are not, however, the only way or even sometimes the best way to mitigate effects, if we consider the larger purpose and spirit of the law. A mitigation program that takes into account the needs of the undertaking and the needs of the resources and that attempts to balance these with considerations of the public benefit will, in the long run, best preserve our heritage and meet the needs of present and future generations.

\section{Data Availability Statement}

No original data were used in this article.

\section{REFERENCES CITED}

Advisory Council on Historic Preservation

2009 Section 106 Archaeology Guidance Questions and Answers: Reaching Agreement on Appropriate Treatment. Electronic document, https://www. achp.gov/Section_106_Archaeology_Guidance/Questions\%20and\% 20Answers/Reaching\%20agreement\%20on\%20Appropriate\%20Treatment, accessed October 24, 2019

Brown, Kenneth L., Marie E. Brown, and Mary Quirolo

2014 Fruitland Coal Gas Gathering Systems Data Recovery Program, San Juan Basin, San Juan, and Rio Arriba Counties, New Mexico. Report 186154-C-01 and 186154-C-02. TRC, Albuquerque, New Mexico.

Chandler, Susan M.

2009 Innovative Approaches to Mitigation. In Archaeology \& Cultural Resource Management: Visions for the Future, edited by Lynne Sebastian and William D. Lipe, pp. 115-139. School for Advanced Research Press, Santa Fe, New Mexico.

Coalition for Archaeological Synthesis

2018 Why a Coalition for Archaeological Synthesis? Electronic document, archsynth.org/why-a-cfas-.html, accessed January 7, 2020.

Ellick, Carol J.

2016 A Cultural History of Archaeological Education. Advances in Archaeological Practice 4:425-440.

Jameson, John H., and Sergiu Musteaţă (editors)

2019 Transforming Heritage Practice in the $21^{\text {st }}$ Century: Contributions from Community Archaeology. Springer Nature Switzerland, Cham, Switzerland.

Klein, Joel I.

1994 Alternatives to Archaeological Data Recovery. Northeast Historical Archaeology 21-22:173-182.

Larralde, Signa, Martin Stein, and Sarah H. Schlanger

2016 The Permian Basin Programmatic Agreement after Seven Years of Implementation. Advances in Archaeological Practice 4: 149-160.

LEAP

2019 Leaders in Energy and Preservation. Electronic document, https://www. energyandpreservation.org/, accessed November 7, 2019.

McManamon, Francis P., John Doershuk, William D. Lipe, Tom McCulloch, Christopher Polglase, Sarah Schlanger, Lynne Sebastian, and Lynne Sullivan

2016 Values-Based Management of Archaeological Resources at a Landscape Scale. Advances in Archaeological Practice 4:132-148.

McManamon, Francis P., Keith W. Kintigh, Leigh Anne Ellison, and Adam Brin

2017 tDAR: A Cultural Heritage Archive for Twenty-First Century Public Outreach, Research, and Resource Management. Advances in Archaeological Practice 5:238-249.

Seaman, Timothy J., William H. Doleman, and Richard C. Chapman

1988 The Border Star 85 Survey: Toward an Archeology of Landscapes. UNM Project No. 185-227. Office of Contract Archeology, University of New Mexico, Albuquerque.

\section{AUTHOR INFORMATION}

Lynne Sebastian $\square$ SRI Foundation, 333 Rio Rancho Drive NE, Suite 103, Rio Rancho, NM 87124, USA (Isebastian@srifoundation.org, corresponding author) 